\title{
Thomas Nashe and Popular Conformity in Late Elizabethan England
}

JENNIFER L. ANDERSEN

Résumé : Le présent article propose que la participation de Thomas Nashe à la controverse "Marprelate » du côté des évêques élisabéthains nous permet de mieux comprendre l'attitude anti-puritaine qui se manifeste à travers son œuvre. Bien que la critique ait eu tendance à représenter Nashe comme proto-journaliste séculaire et amoral, vendant ses services de manière cynique, on peut maintenir que ses écrits font preuve d'une connaissance approfondie de la position polémique des conformistes. Ses attaques contre les Puritains le montrent conscient de ce que les conformistes craignaient dans les revendications puritaines réformatrices, tandis que ses cuvres plus tardives suivent la rhétorique et l'argumentation conformistes comme ces dernières évoluaient d'une campagne négative contre les Puritains vers une défense de l'état actuel des choses.

$\mathrm{M}$ ost of what we know about Thomas Nashe's religious views comes from his own works, because the miscellaneous official papers, autobiographical statements scattered throughout his works, and statements made by his contemporaries tell us little about his life. His father was a curate in Lowestoft, where Thomas Nashe was baptized in 1567. If one may judge from the names of his siblings (Nathaniel, Israel, Mary, Rebecca, and Martha), Nashe's parents seem to have inclined to Puritanism. ${ }^{1}$ Nashe matriculated at Cambridge in 1581, where he was a few terms behind Christopher Marlowe, his friend and occasional literary collaborator, and he graduated B.A. from Saint John's College in 1585-86. By 1588 he had settled in London to seek his living by the pen. Nashe collaborated with writers, printers and patrons throughout his career: Robert Greene gave him an early break by inviting him to write the Preface to Menaphon, and Greene 
later employed him as a researcher for the anti-Marprelate Pasquil pamphlets (from which Nashe then graduated to pen one of the last anti-Martinist tracts, An Almond for a Parrot). Nashe collaborated with Christopher Marlowe in writing Dido, Queen of Carthage, and may have also had a hand in composing the comic subplot of Marlowe's Doctor Faustus. During 1593-94 he seems to have been living with the fledgling printer John Danter and working as a copy-editor. Towards the end of his career, Nashe wrote the no-longerextant play, The Isle of Dogs, with Ben Jonson. Throughout his works, Nashe exhibits a keen awareness of contemporary literary and intellectual fashions through his criticism, emulation and parody of them. The overall picture that emerges is of an entrepreneurial writer who moved in lively London literary and intellectual circles. ${ }^{2}$

While anti-Puritanism used to be recognized as a significant and pervasive element in Nashe's works (both satirical and novelistic), it has slipped out of focus in more recent literary criticism. Even critics such as G. R. Hibbard, who took Nashe's anti-Puritanism seriously, tended to misidentify the position from which Nashe's critique of puritans was launched. Hibbard, along with others, assumed that what Nashe hated about Puritans was their small-mindedness, self-righteous moralism, and anti-intellectualism. ${ }^{3}$ These were, after all, the same Puritans who lobbied so vociferously against the theater in the 1570s and 1580s. Yet, now that research on the Puritan movement informs us that this was a polemically generated, hostile stereotype - as was indeed the term 'puritan' itself — we cannot simply regard Nashe's anti-Puritanism as a laudable repudiation of narrow-minded moralists. Nashe was, in fact, taking advantage of a polemical moment which Patrick Collinson and Alexandra Walsham have called "the invention of Puritanism," and which Peter Lake more precisely describes as the "ideological and polemical relocation of the culture and affect of the self-consciously godly under the signs of hypocrisy, populism and subversion." 4 The particular circumstances and arguments that were marshaled around that polemical moment help explain Nashe's antipathies towards Puritans.

Before reconstructing that context, we should briefly survey some dominant recent approaches to Nashe in order to suggest why a return to a somewhat "old historicist" understanding of his anti-Puritanism is necessary. For the convenience of labels, the two main alternatives to the old historicist interpretation of G. R. Hibbard and R. B. McKerrow that have emerged in Nashe criticism might be called the new historicist and formalist-deconstructionist interpretations. In the new historicist reading, the vertiginous indeterminacy, lack of structure and argument in Nashe's free-associational prose experiments (and the resulting frustrated bafflement of his readers) sends critics in search of broader contexts to explain what is 
happening. Often the larger contexts that get invoked involve narratives about the rise of capitalism, the commodified text, and the professional, commercial writer. Nashe's writing is then treated as a kind of epiphenomenon of these larger historical transitions and processes, and a milestone on the way to modernity. ${ }^{5}$

A corollary of the new historicist Nashe is a portrait of the artist as a free spirit, constrained by a stifling patronage system. In this view, Nashe's creativity and expressiveness are squelched by a patronage system which stands between him and the popular audience he yearns to reach. Lorna Hutson sees the artist giving in to the exigencies of the patronage system, for example, when he registers his Anatomy of Absurdity (1589) with the Stationers' Company. Of Nashe's Anatomy she writes, "no discourse could have been less representative of wit or more stifled by the moralizing reflex Nashe professed to deplore than his bid for patronage, the Anatomie of Absurditie." 6 While Hutson regards Nashe's publication of the Anatomy as selling out, G. R. Hibbard sees the anti-puritanism of the Anatomy as consistent with his "deep-rooted dislike of the Puritans." Hibbard suggests that, "If one of Nashe's intentions in writing the Preface to Menaphon was, as I believe, to recommend himself to those responsible for the anti-Martinist campaign, it soon brought results."7 Both the Preface and the Anatomy evidently succeeded in advertising his polemical skills to the Elizabethan bishops, and it is primarily his anti-Puritanism which would have qualified him as a propagandist for religious conformity. Just as Hutson sees Nashe's Anatomy as a sell-out, so she interprets his involvement in the Marprelate pamphlet wars as a diversion from Nashe's true creative ambitions. Summing up her description of Nashe's employment by Richard Bancroft and John Whitgift, Hutson stresses that "neither of these engagements [to write An Almond for a Parrot and Summer's Last Will and Testament] offered anything like accommodation and protection enough to answer the manifold constraints that the patronage system itself continued to impose upon an author who wished to publish original and independently creative writing." 8 While the attempt at historical contextualization in new historicist interpretations is laudable, the kind of historical processes into which Nashe's prose tends to get assimilated renders him more of a modern than an early modern. Such readings tend to give us Nashe the avatar of modern secular humanism, midwife to realistic fiction and the novel and sundry other hallmarks of modernity.

Another critical approach has tended to limit itself to formal analysis of Nashe's texts. The best work from this group is represented by Neil Rhodes's perceptive reading of Nashe's style, tone and mirthful yet macabre "Elizabethan grotesque" imagery. Other formalist-cum-post-structuralist 
analyses tend to reflect on contemporary narrative and composition theories, rather than on historically grounded features of Nashe's prose. Even the best work produced by this approach would be sharpened and improved by an understanding of the animosities that galvanized Nashe's observed thematic obsessions and stylistic tics. What kind of rhetorical or polemical situations (outside of Nashe's own lurid imagination) elicited his grotesque imagery and unseemly mirth in depicting deformity and suffering? ${ }^{9}$ This brief survey has perforce made artificial distinctions among methods of analysis which are in practice more eclectic and varied, but it illustrates some recent literary critical approaches to Nashe. While each of these approaches has made contributions to our understanding and appreciation of Nashe's methods and madness, a historical understanding of specific rhetorical and polemical situations helps explain the celebrated quirks and quiddities of his style and persona within the larger cultural debates that engaged him.

Part of the impetus for re-inserting Nashe into the context of Elizabethan anti-Puritanism comes from a debate among early modern historians about how cheap print functioned as a conduit and vehicle for Reformation ideas. There is general agreement that pamphlets did play such a role, but historians still disagree about the degree to which any theological precision or sophistication could be conveyed through cheap pamphlets. It is impossible to boil down Alexandra Walsham's and Peter Lake's copiously documented and subtly argued books into a few sentences, but in order to return to the main subject of this essay - Nashe's anti-Puritanism - we need to do just that. Briefly put, for Walsham, religious elements enter into early modern pamphlet literature in an unconscious, collective process of cultural synthesis, a syncretic amalgam of folk belief, medieval tradition, and reformed morality. The congeries of materials recycled from medieval homiletic tradition and joined to a new, market-driven cheap print trade waters down and adulterates any theological content. While Lake also recognizes the processes of commercialization at work in cheap print, and he acknowledges the paradoxes and ambivalences in the contents of pamphlets, nevertheless, he also observes contemporaries using pamphlets to popularize doctrinal tenets. Lake's classic example is the murder pamphlet, which, while capitalizing on innate, morbid curiosity about violent and lurid tales, can also, in the hands of evangelical writers, become a vehicle for advertising the transformative power of repentance and the grace available to repentant sinners. ${ }^{10}$

Walsham's and Lake's divergent interpretations of Nashe's assault on the Puritanism of Philip Stubbes offer one instance of the different polemical charge that each finds in pamphlet sources. For Walsham, Nashe's assessment of Stubbes is credible and unsarcastic; for Lake, "Nashe's assault was 
a wonderfully mischievous attempt to use Stubbes's status as a hack writer to expel him from the ranks of the godly, and his status as a hypocritical, unlearned godly poseur to expel him from the ranks of the genuinely talented literary authors of the city." 11 The analysis of Nashe's anti-Puritan satire that follows has affinities with a Lakeian view of cheap print because it shows Nashe reacting against precisely the kind of puritan appropriations of popular cultural forms that Lake posits. Throughout his prose works, Nashe sends up, lampoons and turns evangelical appropriations of popular genres on their heads. The newly polarized circumstances between Presbyterians and conformists which Lake describes as the context for Nashe's attack on Stubbes were deepened by the Marprelate Controversy. Nashe's most extended attack on Stubbes, in fact, occurs in An Almond for a Parrot, one of the last anti-Martinist pamphlets in the controversial exchange. Although, as we have seen, Nashe's participation in the Marprelate Controversy has been ignored or discounted in recent criticism, his acute grasp of the conformist critique of Presbyterianism (stigmatized as "Puritanism") and his innovative polemical tactics suggest more than a cursory or constrained engagement with these ideas.

The fifth and sixth Marprelate pamphlets had been published in July 1589, a month before the discovery of the Martinist press near Manchester on 24 August 1589. It was somewhat of a surprise, then, when The Protestation of Martin Marprelate - full of misspellings and set in awkwardly fitting and variously sized type - appeared in September 1589. The tone of the Protestation verges on hysteria and desperation. In it, Martin confesses that the seizure of the press and arrest of the printers have turned him to thoughts of his imminent mortality. It is to this pamphlet that Nashe's $A n$ Almond for a Parrot (1589) immediately responds. In the Protestation we find the desperate Martin reduced to self-immolating threats of retributive aggression, tempting, daring, and anticipating his own martyrdom:

\footnotetext{
But tell them from me: that we feare not men who can but kille, the bodye: because we feare that god who can cast both body and soule into vnquenchable fire. And tell them alsoe this. That the more bloode the fearfull sentence pronounced against the persecuters of the truth is executed vpon them, I would then gladly know, whether they who go about thus to sheade our bloode: or we whose blood cryeth for vengeance against them, shall haue the worst ende of the staffe. We are sure to posses our soules in everlasting peace, when soever we leav this earthly tabernacle. ${ }^{12}$
}

Edward Arber's collection of documents relating to the discovery of the Marprelate press includes a letter from William Cecil, Lord Burghley, to Archbishop Whitgift, charging the prelate with finding and shutting down the renegade press. Whitgift's later reply to Burghley reporting the discovery 
of the Marprelate press ends by asking Burghley to enforce the punishment against the culprits:

For my owne parte, in respect of my self (the greatest moate in the[i]re Eye) I make smale account of the[i]re malice, ne[i]ther Dyd I ever break slepe for the care thereof: yet in respect of my calling and profession, and of the scandal that may, by such Lewde Libles be ministred to men apt to beleave anie thing, I could wish them de[a]lt with ac[c]ording to the[i]r Desertes, and the qualitie of the[i]r offens[e]: And that rather by your Lordships then by owre selfes, that the world may know that wee are men not cast off on all sides, as abiects of the world, but that Justice shal as well take place in owre causes, as yt Doth inall other mens, the rather by cause wee susteane iniuries by Martynistes, for Doing of owre Duties in suppressing sects and wicked opinions, and in ma[i]nteyning the state and government by lawe established, which ys wounded thorowe owre sides. ${ }^{13}$

Struggling to maintain the composure of a great prelate and to exhibit an appropriate Christian mercy towards his enemy, Whitgift nevertheless goes on to reveal his considerable ambivalence. While denying that he has lost any sleep or taken personal offense from Martin's pamphlets, in the next breath Whitgift admits that Martin's taunts and allegations have tarnished the office and reputation of bishops. In particular, the characterization of bishops as "persecutors of the truth" and comparison of them to Spanish inquisitors seems to have struck home, to the point that the archbishop asks to be spared the role of enforcing the punishment against the Martinists and their accomplices. Disavowing motives of personal revenge, and struggling to suppress the acrimonious feelings aroused by Martin's libels, Whitgift reminds himself of the consolation and vindication that will come with the punishment of the offenders. While Martin had satisfied himself in the Protestation with the deferred vindication of divine judgment, the punishment which Whitgift gingerly delegates to Burghley in this letter is an all-too-worldly one. Whitgift laments the figurative wounding of the corpus mysticum of the state, as it were, "thorowe owre [the bishops'] sides," interestingly merging the interests of church and state into one body. Whitgift's desire that the punishments of Martinists be meted out by agents of the state rather than the church suggests a desire to define the crime as sedition (rather than as heresy) and to reinforce the bond between lords temporal and spiritual which is at the heart of the conformists' Erastian commitment to episcopal government. On this reading, Whitgift is not simply squirming out of an unsavory duty, but also seeking to turn the trial and punishment of Marprelate rebels into an object lesson in the working of the monarchical state and episcopal government hand-in-hand to secure the realm against traitors. 
The fact that bishops, in the 1586 Star Chamber decree on printing, had been given supervision of the metropolitan presses rendered the Martinists' particular medium of protest - pseudonymous, clandestinely printed pamphlets - a personal slap in the face to the episcopal authorities. Marprelate's defiant acts of publication harked back to Foxe's early Protestant martyrs, whose key test of sanctity was a public declaration of faith. In the Protestation, Martin takes the Elizabethan bishops to task for suppressing the Marprelate press rather than by engaging in arguments in an open disputation "or by any other sound conference or writing" (p. 9). Martin offers to make himself known in an open disputation before the queen "upon danger not only of my libertie but also of my life" (p. 10) and promises to withdraw from debate if the bishops can overthrow him with the word of God. Such a challenge to a public disputation rested on the notion that Thomas Cartwright's arguments were never properly refuted by John Whitgfit. Should Martin defeat his opponents, he would have them "to tusse up and be packing to ROME" (p. 11). Martin equated episcopal censorship with the rituals of silencing enacted in Foxe's Book of Martyrs, comparing the bishops to "Spanish inquisitors," "butchers," and "horse leeches" (p. 3). ${ }^{14}$ Martin's histrionic, romantic gestures of self-sacrifice for his ideals evoke the drama surrounding a judicial ordeal. They exhibit the kind of flourish one might expect from the hero of a chivalric romance, and as we will see, Nashe exploits precisely this generic kinship to typecast the Martinists as lunatic visionaries and quixotic crackpots.

Since Nashe's Almond responds directly to the Protestation, its effectiveness in countering the accusations that discomfited Archbishop Whitgift is one measure of Nashe's skill. Nashe generates unease with Martin's presentation of himself as a genuine saint and complexly manoeuvres the reader's emotional reactions to the text. He derides Martin's attempt to strike a Luther-like pose of defiance in his Protestation (as earlier in the Theses Martinianae):

It may be thou hast read Fox's Monuments more idly, where lighting on the example of Luther, that by his prayers' importunity made the devil to deliver up the obligation of his damnation, that sold the joys of Heaven for the inheritance of earth, thou hopest in like manner in the age of thine iniquities to be restored to eternity by the incessant invocation of the Church which thou termest Antichristian. ${ }^{15}$

Nashe continually advances the notion that the rhetoric of the Marprelate pamphlets is an elaborately constructed, disingenuous performance:

It is not thy despairing protestations can make peace with God, whose church thou hast sought to divide, as did Herod's soldiers his garments: we'll give thee leave to tell us a smooth tale of the intercepting of thy treasons, and curry favor, like a crafty 
fox, with the civil magistrate in politic terms of fear and reverence, but thy heart is no more disguised in this hypocritical apparel than a trencher Aristippus in the coat of a Parasite. $(3,267-77)$

Presbyterians had accused Elizabeth's bishops of dividing and maiming the English church through the partial (because only doctrinal) reformation; here Nashe casts that accusation of divisiveness back in the teeth of the Puritans. Martin's persona is no more than a slick rhetorical construct for the consumption of sympathetic magistrates and gullible lay readers. ${ }^{16}$ The first words of Almond ("Welcome, Master Martin, from the dead, and much good joy may you have of your stage-like resurrection" [2, 130-32]) introduce the persona as a stage character. Nashe takes advantage of the recent discovery of the Marprelate press to offer an exposé of the louche realities lurking behind the swashbuckling persona of Martin. Charles Nicholl suggests that Nashe may have gotten an inside scoop on the story of the Marprelate press's seizure through a connection with Lord Strange, the Earl of Derby, who discovered it. ${ }^{17}$ Nashe drops hints throughout the Almond that he possesses details about the personnel and locations of the secret press: for example, "It was told me by the undaunted pursuivants of your sons, and credibly believed in regard of your sins, that your grout-headed holiness had turned up your heels like a tired jade in a meadow ..." $(2,132-35)$. He mines details from the report of the discovery of the press to characterize the manufacture of Marprelate pamphlets as a ramshackle affair supported by semi-literate cobblers and social malcontents: these were the upstarts who had so vexingly thumbed their noses at the ecclesiastical establishment and its ostensible control of the press.

Nashe quotes Martin's defiantly heroic statements, interjecting editorial doubts and queries:

\footnotetext{
We fear not men that can kill the body, quoth Martin, because we fear God, who can cast both body and soul into unquenchable fire. Dost thou fear God indeed? I pray thee, good hedgecreeper, how shall we know that? What, by the smoothing of thy face, the simpering of thy mouth, or staring of thy eyes? Why, if that be to fear God, I'll have a spare fellow shall make me a whole quest of faces for three farthings. (4, 386-95)
}

What Martin professes to feel (fear of God) cannot be tested other than through superficial, easily faked gestures. Later, Nashe inverts and re-writes Martin's imagined scene of suffering and martyrdom. If Martin's melodramatic evocation of his predicament is indeed a manipulative fiction, if the rhetoric of desperation is a tear-jerker calculated for popular consumption, the tears that will flow from Nashe will not be out of pity for Martin as a 
persecuted victim, but for the torments he and his erring brethren will suffer in hell:

The humors of my eyes are the habitations of fountains, and the circumference of my heart the enclosure of tearful contrition, when I think how many souls at that moment shall carry the name of Martin on their foreheads to the vale of confusion, in whose innocent blood thou swimming to hell, shalt have the torments of ten thousand sinners at once, inflicted upon thee . . . Mercy will say unto thee, I know thee not, and Repentance, what have I to do with thee? $(6,614-27)$

Nashe converts the readerly expectations built up by Martin's rhetoric of passive resistance. He demands that readers examine their empathy and become alert to the emotional manipulation at work; the feelings and impulses that Martin has released must be corrected and disallowed. In Nashe's rendition of the drama of the last judgment, Martin's soul is destined for hell, along with those of his hapless followers. Nashe neatly appropriates the pose of contrition, so central to Puritan affect and belief, to his own narrator, in pointed contrast to the unrepentant Martin. The appropriation of a godly, holier-than-thou rhetoric of righteous superiority is completed a few lines later:

And thus much, Martin, in the way of compassion, have I spoke for thy edification, moved thereto by a brotherly commiseration, which, if thou be not too desperate in thy devilish attempts, may reform thy heart to remorse, and thy pamphlets to some more profitable theme of repentance. $(6,646-52)$

Here the Puritan keywords - "edification," "brotherly commiseration," "remorse," and "repentance" - line up in a gleeful little dance over Martin's grave. Nashe's professed "compassion" and regret for the fate of Martin and his followers emerges, by the end of the Almond, as a facetious parody. Again, Nashe's adoption of the rhetoric of his opponent is instructive: it alerts the reader to the ethical and emotional charge of such rhetoric, and to the relative ease with which it may be adopted by any smooth talker. In this instance, for example, a pose of irenic moderation, of reacting more in sorrow than in anger, masks violent aggression. ${ }^{18}$

Another part of the Presbyterian platform repudiated by Nashe is the claim to higher learning and standards of education. Presbyterians placed great weight on the need for a more educated, preaching clergy, not only for the edification of individual souls, but also because they believed that the scriptural injunction to edify, once carried out, would realize the divine plan for a heavenly kingdom on earth. As the demand for a preaching clergy met with resistance, anecdotes about illiterate preachers became a staple of Presbyterian agitation. Dean John Bridges, whose Defence of the Government Established in the Church of England (1587) provided the groundwork 
of the Martinist attack, tried to redefine edification as a conformist concept. According to Lake, Bridges and Thomas Cooper, who were the first to respond to the Marprelate pamphlets, represented a moderate anti-presbyterianism, and the constraints of the conformist position limited Bridges to advancing a rather lackluster meaning of edification. ${ }^{19}$

Martin Marprelate, having come down from the high horse of disciplined, academic, scripturally supported disputation, to the polemical equivalent of the cucking stool, now gave the conformists the perfect opportunity to reclaim the title of true defenders of learning. Nashe did not waste the opportunity, but pointed to the vulgar methods of Martin Marprelate as the basis for a series of intellectual put-downs. It is important to remember here that "old historicist" critics like Hibbard assumed that Nashe hated puritans for their anti-intellectualism. Hibbard rightly observed that Nashe frequently denigrates puritan intelligence and sophistication. We must see these slurs, however, as part of a dialectical move in the anti-Puritan campaign rather than as a faithful representation of sociological reality. Nashe was taking advantage of the polemical opportunity that opened up with the Marprelate controversy to enjoy a field day against Puritans. The pallid definition of "edification" devised by Bridges and other conformist apologists must have been a source of frustration to university-educated conformists like Nashe, who could now present a more robust defense of learning.

Nashe's caricature of Thomas Cartwright reiterates the gamut of antipuritan stereotypes: he accuses Cartwright of propounding the self-image of a martyr-saint to the Presbyterian cause, of pandering to the prejudices of the uneducated masses, and of hiding radical and subversive intentions beneath a cloak of moderation:

No sooner had these newfangled positions [Cartwright's ideas] entered the tables of young students, but Singularity, the eldest child of heresy, consulted with malcontented melancholy how to bring this misbegotten schism to a monarchy. To which purpose hypocritical zeal was addressed as a pursuivant into all places of Suffolk, Norfolk, Essex and Middlesex, with express commandment from the synod of Saints to proclaim Thomas Cartwright supreme head of the Church. $(8,928-38)$

When Nashe traces the root of Cartwright's transgression and heresy to "singularity," he avoids engaging with the particular points of Cartwright's anti-prelate arguments and turns the Presbyterian leader into the prime offender against the central watchword of conformist polemics, union. As Collinson has argued, union was a key aspect of the new and confident episcopalian ideology of the 1590s. Nashe's personified vices in the morality tale of Cartwright's fall - singularity, heresy, melancholy and zeal — seem designed to define the arch-sin of Puritanism as a perverse resistance to 
conformity. Here is a perfect example of the process described by Lake, in the passage cited earlier, as the "ideological and polemical relocation of the culture and affect of the self-consciously godly under the signs of hypocrisy, populism and subversion." Emblazoned with these Puritan neuroses, Cartwright and his disciples then participate in a mock-Spenserian allegory which overturns and inverts heroic Puritan self-representations and myths. ${ }^{20}$

Nashe creates a fictional genealogy of Presbyterianism, deriving the origin of Martinist upstarts and rebels from Cartwright: "Thomas Cartwright in Cambridge first invented this violent innovation, when as his mounting ambition went through every kind of Ambitus, to compass the office of the Vice-chancellorship" $(8,911-15)$. The tale of Cartwright's university career and extended debate with Whitgift continues in the manner of a chivalric romance, with an episode reminiscent of Redcrosse Knight's encounters with Archimago and Error in Book I of The Faerie Queene:

This past on thus, whiles the sword of justice slept in his [Cartwright's] scabbard, whose unprovident eye, neglecting the beginning of such burnings, hath added a more confirmed fury to the flame, which hath now taken hold on the buildings of our bishoprics. How it hath raged in those quarters before mentioned, to the utter impoverishing of the allegiance of the communality, and lamentable undoing of the estimation of divers other knights and gentlemen, the whole course of the high commission may testify. Neither was this plague of apostasy undeserved of their inconstancy, who forsook the true service of God, to worship the idol of Warwick. Put case his reading be great and his malice more, that he hath plodded through ten cart load of paper, and been the death of ten thousand pound of candles, yet . . Whatsoever is done doth vanish to infamy, if it be not upholden by humility. $(8,928-58)$

Here Nashe confuses Cartwright with the fictional knight Guy of Warwick ("the idol of Warwick") to mock his popular cult following. McKerrow glosses the "idol of Warwick" as a roundabout reference to Cartwright, ${ }^{21}$ which it undoubtedly is, but the deliberate ambiguity of the periphrastic epithet, I would argue, is also intended to call attention to the similarities between the Puritan champion and the medieval chivalric hero. Predictably, like Redcrosse Knight, Cartwright is overcome by the monster pride ("Pride ... will also confound arrogant Thomas Cartwright and all his accomplices in the Lord's good time" [8,972-77]). One of the things Nashe attempts to imply through such a mock-heroic caricature is that this is roughly how popular adherents to Puritanism view the Presbyterian champion. Not capable, clever, or subtle enough to follow the intricacies of Cartwright's high theological disputation with Whitgift, he implies, common folk are drawn to the Presbyterian leader by the audacity and subversive energy of his bold stand-off with a grandee of the ecclesiastical hierarchy. Escapist fantasies shaped by old romances, Nashe implies, feed the popular adherence to his 
cause. Polemical intentions aside, this was a perceptive bit of genre criticism on Nashe's part, since modern critics have seen a connection between hagiography and romance as well. ${ }^{22}$

Nashe's parody of the Presbyterian tendency to characterize the struggle with their conformist foes in eschatological terms receives an uncanny validation in later printed replies by Cartwright and John Penry to the anti-Martinist campaign. Cartwright introduces his Brief Apologie (1596) as "the right pourtraicture of Innocency truly laied foorth unto thee in her proper lineaments," while Penry brands Nashe's Almond as an attempt of Satan to "infect the aire ... with all his contagions." 23 Cartwright's prosopopeia and Penry's eschatology were more than just rhetorical flourishes: they were part of a deep-seated belief that pamphlets had become the battleground for a conflict between allegorically expressed forces of good and evil. The godly were informed by the divine truth of scripture while their enemies became perforce the godless and lewd instruments of the devil. Conformist apologists like Whitgift, by contrast, argued that no human being was capable of drawing the line between the visible and invisible church, the elect and the reprobate. The church's membership would always, rather, contain an inextricable mixture of the godly and the profane. Nashe does not so much refute Cartwright's logic as deconstruct his rhetoric. Focusing on the Puritan habit of allegory, and parodying allegorical modes of thought as fanciful and symptomatic of Puritan pathologies, Nashe fleshes out the stereotype of Puritan isolation, eccentricity, and singularity - all ranged in perverse opposition to the neighborly, down-to-earth, and solid-citizen conformists.

The notion that Cartwright was regarded as a saint by the puritan brethren appeared in a full-blown accusation when Matthew Sutcliffe alleged that a "legend of Mr. Cartwright his miracles" was being passed from hand to hand among the brethren. Cartwright answered this slander in a pamphlet addressed to Sutcliffe, where Cartwright denies fostering such a cult and invites Sutcliffe to examine inhabitants of his hometown to see whether any such legend was ever cultivated by him. As Sutcliffe suggests in his counter-response, Cartwright's defense somewhat misses the point, because whether or not he personally sponsored such a cult, once such ideas were circulating in the public arena, damaging and seditious acts could be perpetrated in Cartwright's name. The Frantick Hacket Affair was a perfect example of the kind of sectarian craziness that could result from the undisciplined zeal of the Puritan movement's popular followers. Even though Cartwright denied having any involvement with Hacket, just as he denied propagating a cult of his own miracles, his conformist opponents repeatedly made these allegations. ${ }^{24}$ Whether or not Cartwright condoned it, they were 
suggesting, he had become something of an icon or hero for the radical wing of the Presbyterian cause.

Puritan mock-hagiographies became something of a specialty for Nashe, who had written one for Philip Stubbes in Anatomy of Abuses and would later write one for Gabriel Harvey. Nashe goes on in the remainder of the Almond to paint devastating portraits of Eusebius Paget, Giles Wiggenton and John Udall, only the last of whom was actually connected with the Martinists. The coup de grâce comes in his portrait of John Penry, whom he identifies as Martin himself. In a viciously splenetic description, Nashe appropriates the providentialized rhetoric of prodigy pamphlets to describe Penry as a "monster of Cracovia":

As he was begotten in adultery and conceived in the heat of lust, so was he brought into the world on a tempestuous day, and born in that hour when all planets were opposite. Predestination, that foresaw how crooked he should prove in his ways, enjoined incest to spawn him splayfooted. Eternity, that knew how awkward he should look to all honesty, consulted with Conception to make him squint-eyed, and the devil, that discovered by the heavens' disposition on his birthday, how great a limb of his kingdom was coming into the world, provided a rusty superficies wherein to wrap him as soon as ever he was separated from his mother's womb. . . (11, 1255-69)

Here he appropriates and sends up Puritan providential interpretations of monstrous births, interpreting the supposed deformities of the infant Penry as signs of reprobation (with a wicked pun on superficies, meaning both superficiality and feces). This is a perfect example of a conformist satire of the puritan appropriation of the discourses of providence and predestination, especially as these were glossed and disseminated to a popular audience in prodigy pamphlets of strange births and natural disasters. For natural disasters, such as dearths, plagues and deformed births, were habitually interpreted by Presbyterian propagandists as warnings of the approaching wrath and judgment of God to be visited on a country which refused to conform to the will of God. Here Nashe exultantly turns the tables on a Puritan appropriation of popular predestinarian discourse. In his usual satiric vein, Nashe writes inside the genre (exhibiting its conventional features) but outside it at the same time (through grotesque exaggeration of its conventions). ${ }^{25}$

It was no doubt a passage such as this that elicited Penry's outraged reaction in print a few months later. After censuring elements of Bancroft's notorious 1589 Paul's Cross sermon, the pamphleteer reserves more vehement condemnation for Nashe's Almond:

The devill indeede hath been within this twelvmoneth, shewed himselfe to bee grievously wounded in their persons [the bishops], because he hath raged so mightily, 
as these 32. yeares his furie was never seene so great against the truth as at this present. That vile and scurrilous Pamphlet, lately suffered to come abroad by their privity (if not allowance) and in their defence doeth evidently shew, that sathan feeleth the power and sway which he was wont to bear by vertue of the hierarchie, to be greatly weakned. And because he feareth that his time under their government cannot be long, therefore he meaneth now to infect the aire at once, with all his contagions. The strength which they get by such leud and filthy stuffe, $\&$ the discredit which thereby they worke either unto the cause, or the men and women whome they suffer to bee so unworthilie traduced, is noe other then it were to bee wished (that seeing they will needs be filthy) they would publish such another booke every day: That then it might appeare indeede whose sonnes they are. And this is all the confutation that I thinke, so godles \& leud a scrole to deserve. ${ }^{26}$

Printed in the margin next to "that vile and scurrilous Pamphlet" are the words "An almond for a Parrot as the lewd and offensive pamphlet in question." The subtlety and humor of Nashe's satiric appropriation and sending up of puritan rhetoric and genres evidently escaped Penry.

Another anonymous pamphlet from 1591 also responded with outrage to Nashe's Almond, raising the question, "Whether it be agreeable to the word of God, law of England, and practise of any well gouerned Church to punish that which is taken for slaundering, ribaudry \& villanie with returne of libels, ribaudrie and vallainie. And whether Almond for the Parret, Martins Monethes minde \&c doe not as much offend that way, as Martin Marprelate, or if they offend at all, why are they suffered, not punished."27 Bishop Matthew Sutcliffe undertook to answer this charge in An Answer to a Certain Libel (1592), where he offers a complicated defense of the anti-Marprelate campaign. According to Sutcliffe, "Whatsoever those did, that answered Martins ribauldry bookes, they did it of their owne heads, without either knowledge or allowance of their superiors: and therefore let them answere themselves" (p. 153). Besides the objections of the anonymous petitioner, we should remember that in the extended passage from Brief Discovery cited above, Penry alleges the bishops' direct sponsorship of the anti-Martinist pamphlets, "by their privity (if not allowance)." Sutcliffe anticipates such an objection when he continues, "If this Questioner reply and aske, why are they not called in? it may be answered, that if he wil make himself party, \& shew any thing in them against religion or law, they wil be called in: yea \& some of them haue been called in, and others of a more biting stile and nature haue bene stayed. ..." Summing up his argument, he goes back on the offensive: "First then I answer that the books which were written against Martin, are more tolerable and wittie, then Martin, although they were not allowed. Secondly, that it is as absurd for Libellers to complayne of Libelling, as dogges that byte, of byting ... And 
lastly, that not onely Martin's madde deuises, but also this Sycophantes writings are against lawe, yea, against common humanitie" (p. 154).

It is telling that this denial comes from Bishop Sutcliffe, rather than from another prolific anti-puritan propagandist of the 1590s, Richard Bancroft, since it is supposed that Bancroft was responsible for employing the anti-Martinist pamphleteers, including Nashe. ${ }^{28}$ Nashe seems to allude to his episcopal sponsorship in his parting comments to Penry towards the end of an Almond ("but if authority do not moderate the fiery fervence of my enflamed zeal, I'll assail thee from term to term" [12, 1422-24]), and it is reasonable to assume episcopal sponsorship, since allowance to print came, after all, from episcopal authorities. In denying that the anti-Martinist pamphlets were allowed by the bishops, Sutcliffe simultaneously invokes them as an example of autonomous, popular support for episcopal policy , and plausibly denies any episcopal role in instigating the pamphlet campaign.

It is difficult, after reviewing the anti-Puritanism in Nashe's early works, to accept the notion that his literary ambitions were set solely on reaching a popular audience. He disparages Puritans and Martinists for aiming at precisely such popularity in their hi-jacking of cheap pamphlet forms and popular legends to proselytize to the vulgar. In Almond he debunks Puritan rhetoric of martyrdom, as well as Puritan claims to higher education, obedience and moderation. Before the Marprelate controversy, pamphleteers and ghost writers who had proven themselves useful to patrons within the Elizabethan governing establishment had found protection and employment, and Nashe had every reason to expect that he might reap such rewards from his loyal service to the bishops. Unlike writers who were able to carve out such a niche for themselves, however, things did not work out so well for Nashe. Even though he wrote for what could be considered the winning side in the controversy, the criticism of the anti-Martinist campaign as pulpit bullying and the consequent need of the bishops to distance themselves from anti-Martinist writers left Nashe unprotected. One of the great advantages to the use of an independent agent like Nashe, the plausible deniability it afforded his sponsors, ended up, paradoxically, denying him the protection and patronage that he sought. ${ }^{29}$

In the course of the 1590s, Nashe seems to have become a lightning rod for Presbyterian and municipal discontents: he got into trouble for Christ's Tears Over Jerusalem, The Isle of Dogs, skated on the edge of propriety with "The Choice of Valentines," and was ultimately named personally in the Bishops' Ban on satire in 1599. Nashe's abandonment by his ecclesiastical patrons puts his notorious bitterness about literary patronage and his frustration with working as a hack writer in a different light. We must look not 
only to market forces, but, more importantly, to the cut-and-thrust of late Elizabethan ecclesio-political polemics to understand Nashe's preoccupations and misfortunes. Finally, and keeping in mind Robert Miola's essay on Ben Jonson's religion in this volume, we should consider the closing lines of Jonson's moving epitaph for Thomas Nashe:

\author{
thou diedst a Christian faithfull penitent \\ Inspired with happie thoughtes \& confident \\ This thoughte thie latest grace was not the least \\ Which still shall lyue when all else are deceast \\ farewell greate spirite my pen attird in blacke \\ shall whilst I am still weepe \& mourn thie lacke. $(25-30)^{30}$
}

\title{
Notes
}

1. Nicholas Tyacke discusses Puritan naming habits in "Popular Puritan Mentality in Late Elizabethan England," in The English Commonwealth 1547-1640: Essays in Politics and Society presented to Joel Hirstfield, ed. P. Clark, Alan G.R. Smith and Nicholas Tyacke (Leicester: Leicester University Press, 1979), pp. 77-92.

2. Biographical information about Nashe summarized here is taken from $D N B ; \mathrm{R}$. B. McKerrow, "Introduction," The Works of Thomas Nashe, vol. 5 (Oxford: Basil Blackwell, 1958), pp. 1-64; and Charles Nicholl, A Cup of News: the Life of Thomas Nashe (London: Routledge and Kegan Paul, 1984).

3. G. R. Hibbard, Thomas Nashe: A Critical Introduction (London: Routledge and Kegan Paul, 1962), pp. 39, 47.

4. Patrick Collinson, "The Theatre constructs Puritanism" in The Theatrical City: Culture, Theatre and Politics in London 1576-1649, ed. David L. Smith, Richard Strier and David Bevington (Cambridge: Cambridge University Press, 1995), pp. 157-69, and "Ecclesiastical Vitriol: Religious Satire in the 1590s and the Invention of Puritanism," in The Reign of Elizabeth I: Court and Culture in the Last Decade, ed. John Guy (Cambridge: Cambridge University Press, 1995), pp. 150-69; Alexandra Walsham, "'A Glose of Godllines': Philip Stubbes, Elizabethan Grub Street and the Invention of Puritanism" in Belief and Practice in Reformation England: A Tribute to Patrick Collinson from His Students, ed. Susan Wabuda and Caroline Litzenberger (Aldershot: Ashgate, 1998), pp. 177-206. Peter Lake's gloss appears in The Antichrist's Lewd Hat: Protestants, Papists and Players in Post-Reformation England (New Haven, CT: Yale University Press, 2002), p. 570.

5. Some examples of this approach are Lorna Hutson, Thomas Nashe in Context (Oxford: Clarendon Press, 1989); Henry S. Turner, "Nashe's Red Herring: Epistemologies of the Commodity in Lenten Stuffe," ELH 68 (2001): 529-61; Kenneth Friedenreich, "Nashe's Strange News and the Case for Professional Writers," Studies in Philology 71 (1974): 451-72; James Nielson, Unread Herrings: Thomas Nashe and the Prosaics of the Real (New York: Peter Lang, 1993); and Sherri Geller, "Commentary as Cover-up: Criticizing Illiberal Patronage in Thomas Nashe's Summer's Last Will and Testament," English Literary Renaissance 25 (1995): 148-78.

6. Hutson, p. 67. 
7. Hibbard, pp. 27, 36. If Peter Blayney's research into the very modest profits made on playbooks is any indication of the money to be made on the kind of pamphlets Nashe wrote, the notion that Nashe aspired to become an independent, professional writer seems implausible. See Peter W. M. Blayney, "The Publication of Playbooks" in A New Hstory of Early English Drama, ed. John D. Cox and David Scott Kastan (New York: Columbia University Press, 1997), pp. 383-422.

8. Hutson, p. 68.

9. See Neil Rhodes, Elizabethan Grotesque (London: Routledge and Kegan Paul, 1980), and Jonathan V. Crewe, Unredeemed Rhetoric: Thomas Nashe and the Scandal of Authorship (Baltimore: Johns Hopkins University Press, 1982).

10. See Alexandra Walsham, Providence in Early Modern England (Oxford: Oxford University Press, 1999); Peter Lake, "Deeds against Nature: Cheap Print, Protestantism and Murder in Early Seventeenth-Century England," in Culture and Politics in Early Stuart England, ed. Kevin Sharpe and Peter Lake (Stanford, CA: Stanford University Press, 1993), pp. 257-83. Other studies relevant to this argument are Sandra Clark, The Elizabethan Pamphleteers: Popular Moralistic Pamphlets 1560-1640 (Rutherford, NJ: Farleigh Dickinson University Press, 1983), and Tessa Watt, Cheap Print and Popular Piety, 1550-1640 (Cambridge: Cambridge University Press, 1991).

11. Walsham, "'A Glose of Godllines,"” pp. 177-206; Lake, The Antichrist's Lewd Hat, pp. 563-76.

12. The Protestatyon of Martin Marprelate is quoted from The Marprelate Tracts (15881589) (rpt. Leeds: Scolar Press, 1967), p. 5. All further quotations from this text will be cited in the body of the essay.

13. Edward Arber, ed., An Introductory Sketch to the Martin Marprelate Controversy 1588-1590 (London: Unwin Brothers, 1880). The passage from Whitgift's letter is taken from p. 113; Burghley's letter appears on pp. 107-8. On the symbolic significance surrounding state executions, see Peter Lake and Michael Questier, "Agency, Appropriation and Rhetoric under the Gallows: Puritans, Romanists and the State in Early Modern England,” Past and Present 153 (1996): 64-107.

14. For Protestants, as Robert Kolb has observed, the act of martyrdom focused on verbal declarations of faith, rather than on physical suffering, as it had for the medieval saints such as Margaret and Christina; see Robert Kolb, For All the Saints: Changing Perceptions of Martyrdom and Sainthood in the Lutheran Reformation (Macon, GA: Mercer University Press, 1987). See Arber, ed., pp. 50-51 for the Star Chamber decree on printing.

15. An Almond for a Parrot, in A Concordance to the Works of Thomas Nashe, by Louis Ule, 2 vols. (Hildesheim: Olms-Weidmann, 1997), 2: 3, 11. 253-60. All further quotations are cited by page and line numbers in the body of the text. Even though McKerrow included several of the anti-Martinist Pasquil pamphlets in his edition of Nashe's Works, An Almond for a Parrat is now the only one thought certainly to be by Nashe. On the attribution of the Almond to Nashe, see Hibbard, pp. 37-48, and Nicholl, pp. 72-79.

16. As Peter Lake explains (Anglicans and Puritans? Presbyterianism and English Conformist Thought from Whitgift to Hooker [London: Unwin Hyman, 1988], p. 75), moderate Puritans stressed that their view of the spiritual sanctions of the church left the civil power of the magistrate untouched.

17. See Nicholl, pp. 88-89, and Arber, ed., pp. 114-16. 
18. In "Anti-Puritanism, Anti-Popery and the Rhetoric of the Gallows in Thomas Nashe's The Unfortunate Traveller," Sixteenth Century Journal (forthcoming, 2004), I discuss similar manipulations and corrections of readers' responses in Nashe's later prose fiction.

19. Lake, Anglicans, p. 123. On the Presbyterian concept of edification more generally, see John S. Coolidge, The Pauline Renaissance in England: Puritanism and the Bible (Oxford: Clarendon Press, 1970); on means devised to educate ignorant clergy, see Patrick Collinson, The Religion of Protestants: The Church in English Society 1559-1625 (Oxford: Clarendon Press, 1982), pp. 121-35; on the initial exchange between Bridges and Martin Marprelate, in particular, see John S. Coolidge, "Martin Marprelate, Marvell, and Decorum Personae as a Satirical Theme," PMLA 74 (1959): 526-32.

20. For Collinson's point about union, see Religion, p.12. See Anne Lake Prescott's essay in this volume for pertinent interpretations of Book I of Spenser's The Faerie Queene.

21. See McKerrow, ed., vol. 4 (1958), p. 467, n. 31.

22. D. R. Woolf discusses connections between hagiography and romance in "The Rhetoric of Martyrdom: Generic Contradiction and Narrative Strategy in John Foxe's Acts and Monuments," in Rhetorics of Life-Writing in Early Modern Europe, ed. Thomas F. Mayer and D. R. Woolf (Ann Arbor: University of Michigan Press, 1995), pp. 243-73.

23. Thomas Cartwright, A Brief Apologie (London, 1596), sig. A2 ${ }^{\mathrm{r}}$; John Penry, A Brief Discovery of the Untruths (Edinburgh, 1589), sig. A4 ${ }^{\mathrm{r}}$. Cartwright's extended personification of Innocency illustrates many of the features which Nashe parodies:

Being thou seest thus prouoked as shee is, or rather, to speake the trueth, thus violentlie drawne into th'encounter by the wretched assaultes of an unlearned mouth, yet marke, I pray thee, howe shee caries her selfe, and how shee comes armed into the fielde, Patience, Mildnesse, Trueth, and a good Conscience: This is her armour, these her weapons. ... ( $\left(\right.$ sig. A $\left.2^{\mathrm{r}}\right)$

24. See Matthew Sutcliffe, An Answere to a certaine libel supplicatorie (London, 1592); Thomas Cartwright, A brief Apologie (London, 1596); and Matthew Sutcliffe, The Examination of M. Thomas Cartwrights late apologie (London, 1596; rpt. New York: Da Capo Press, 1993). All further references to these pamphlets will be noted by page number within the body of the text. Peter Milward provides a bibliography for the Marprelate Controversy and consequent pamphlet disputes in Religious Controversies of the Elizabethan Age: A Survey of Printed Sources (London: Scolar Press, 1978). On the Frantick Hacket Affair, see Alexandra Walsham, “'Frantick Hacket': Prophecy, Sorcery, Insanity, and the Elizabethan Puritan Movement," Historical Journal 41 (1998): 27-66.

25. Elsewhere Nashe repeatedly derides credulity in prodigy pamphlets. See Anatomy of Absurdity, in Ule, 1: 7, and Lenten Stuff, in Ule, 2: 157. Incidentally, Walsham cites Nashe's comments about prodigy pamphlets in Lenten Stuff as a general criticism of the credulity of common readers, whereas I take such comments as part of a pointedly anti-Puritan polemic; see Walsham, Providence, p. 223.

26. Penry, A Brief Discovery, sig.A4r. Although this pamphlet was printed anonymously, the English government suspected John Penry of writing it, and the ESTC now lists Penry as the author and Robert Waldegrave as the printer. For a discussion of the pamphlet, see Owen Chadwick, "Richard Bancroft's Submission," The Journal of Ecclesiastical History 3 (1952): 59. 
27. A petition directed to her most excellent Maiestie (London, 1591), p. 76.

28. See Stuart Babbage, Puritanism and Richard Bancroft (London: SPCK, 1962), who considers that Whitgift's testimony on behalf of Bancroft in order to get him elected to the bishopric of London in 1597 is the best evidence for Bancroft's direct involvement in the search for the Marprelate press and in having the idea "to have them answered after their own vein in writing" (p. 40).

29. In "Puritans, Papists and Players: Was There a 'Public Sphere' in Elizabethan England?", in The Politics of the Public Sphere in Early Modern England, ed. Peter Lake and Steven Pincus (Manchester University Press, forthcoming) Lake discusses propaganda campaigns connected with the Anjou Match, the Campion Affair, the Anti-theatrical Controversy, and the Marprelate Controversy, in which writers like John Stubbes, Thomas Norton, Stephen Gosson, and Anthony Munday received patronage from members of the ruling class. I am grateful to Professor Lake for sharing his unpublished research.

The comments of Penry and the anonymous petitioner on the anti-Martinist pamphlets were only two of many criticisms of the anti-Martinist campaign. Richard and Gabriel Harvey called for reconciliation. At a higher level of government, Francis Bacon chastised the bishops for stooping to employ the anti-Martinist writers in what seems to have circulated as an unprinted government brief: see "An Advertisement Touching the Controversies of the Church of England," in Francis Bacon, ed. Brian Vickers (Oxford: Oxford University Press, 1996), pp. 3-4.

30. Katherine Duncan-Jones, "'They say a made a good end': Ben Jonson's Epitaph on Thomas Nashe,” Ben Jonson Journal 3 (1996): 2. 